\title{
PROCESSO ADMINISTRATIVO DISCIPLINAR. ALEGAÇÕES E RELATÓRIO ORAIS. LEGALIDADE
}

\author{
ADMINISTRATIVE DISCIPLINARY PROCEDURE. ORAL ARGUMENTS AND REPORT. LEGALITY
}

\author{
Roberto Augusto de Carvalho Campos* \\ Ivanira Pancheri*
}

\begin{abstract}
Resumo:
Cinge-se ao tema da legalidade da apresentação de Alegações Finais e respectivo Relatório Final, de forma oral, em sede de Procedimento Administrativo Disciplinar. Noutros termos, cuida-se de questionamento acerca da higidez procedimental em face de Alegações Finais e Relatório Final verbais. A relevância do debate tem como cerne o Devido Processo Legal. Como hipótese, parte-se da concepção primordial de uma nulificação processual. Discorre-se historicamente sobre os planos de existência, validade e eficácia. E, primordialmente, sobre o hodierno conceito de nulidade absoluta e nulidade relativa. Não se olvide todavia que, ao lado destes grandes nortes, há inteligências dissonantes que serão devidamente analisadas. Sob uma metodologia monotemática, teórica e científica, investiga-se material bibliográfico para solver assunto contemporâneo e de importância à Administração Pública. A partir da premissa de que existe um tipo processual que traduz a avaliação de valores do legislador, prestando para assegurar garantias constitucionais do sistema processual, alcançou-se a ilação acerca da imprescindibilidade de nulificação. Destarte, o deslinde é no sentido de uma declaração de nulidade absoluta do procedimento disciplinar a partir das Alegações Finais inclusive, com refazimento de todos os atos processuais decorrentes.
\end{abstract}

Palavras-chave: Processo Administrativo Disciplinar. Alegações Finais verbais. Relatório Final verbal. Nulidade Absoluta.

\begin{abstract}
:
This paper aims to analyze the legality of submitting final allegations its Final Report, orally, in the seat of Administrative Disciplinary Procedure. In other words, the authors challenge the verbal procedural final allegations and Final Report. The relevance of the debate is about the due process of law. As a hypothesis, this
\end{abstract}

Possui graduação em Medicina pela Universidade Federal de São Paulo-Escola Paulista de Medicina (1982), graduação em Direito pela Universidade Presbiteriana Mackenzie (1997), mestrado em Otorrinolaringologia e Cirurgia de Cabeça e Pescoço pela Universidade Federal de São Paulo (1995) e doutorado em Medicina pela Universidade Federal de São Paulo (2000). Atualmente é Professor Doutor do Departamento de Direito Penal, Medicina Forense e Criminologia da Faculdade de Direito do Largo de São Francisco-Universidade de São Paulo. Tem experiência na área de Neurocirurgia, Direito Médico e Medicina Legal, atuando principalmente nos seguintes temas: bioética, biodireito, deontologia e otoneurologia.

** Pós-doutoranda pela Universidade de São Paulo. Doutora pela Faculdade de Direito da Universidade de São Paulo em Direito Penal. Mestre pela Faculdade de Direito da Universidade de São Paulo em Direito Processual Penal. Especialista em Direito Ambiental pelas Faculdades Metropolitanas Unidas. Procuradora do Estado de São Paulo. Docente. Artigo Científico elaborado a partir de Parecer desenvolvido junto à Consultoria Jurídica da Secretaria de Administração Penitenciária. 
paper assumes the primordial conception of a procedural nullification, including historical development from the existence, validity and effectiveness plans, and the current concept of absolute and relative nullities. Alongside these great horizons, there are dissonant arguments that will be duly considered. Under a monothematic theoretical and scientific methodology, the authors investigate bibliographic materials to understand the contemporary subject matter and importance to the Public Administration. From the premise that there is a procedural type that reflects the assessment of the legislator values, paying to ensure constitutional guarantees of procedural system, one reached the consciousness of the indispensability of nullification. Thus, the demarcation is towards an absolute invalidity of the disciplinary proceedings from the final allegations.

Keywords: Administrative Disciplinary Procedure. Final verbal allegations. Verbal final report. Absolute nullity.

\section{Introdução}

A altercação derradeira que pende deste artigo é a legalidade ou não da apresentação de Alegações Finais e respectivo Relatório Final, de forma oral, em sede de Procedimento Administrativo Disciplinar.

Noutros termos, questiona-se aqui acerca da higidez processual diante de Alegações Finais verbais e correspondente Relatório também, oral. Cuida-se de discussão preliminar e independente do mérito.

A relevância do debate inclui como cerne o Devido Processo Legal, sabidamente presente desde a Carta Magna de 1215 que, de maneira autônoma ao resultado, ostenta força o bastante para dar desfecho de Nulificação processual, quando desrespeitado.

Destarte, se o procedimento ocorrer ao largo dos parâmetros legais, a nulificação far-se-á fundamentada.

É exatamente desta hipótese que se versará nesta peça.

2. Desenvolvimento

2.1. Conceitos. Existência. Validade. Eficácia. Nulidade Absoluta e Relativa

Principiemos por considerações sobre os distintos planos da existência, validade e eficácia dos atos jurídicos.

De sabença, o ato jurídico é espécie do gênero fato jurídico.

Se por fatos jurídicos tem-se, consoante conhecida máxima de Savigny, "aos acontecimentos em virtude dos quais as relações de direito nascem e terminam", atos jurídicos caracterizam-se por especial categoria, definidos então, por fatos "cujo suporte tenha por cerne uma exteriorização consciente de vontade, que tenha por objeto obter 
um resultado juridicamente protegido ou não proibido ou possível". (SAVIGNY apud DARCIE, 2011, p. 100).

Estes fatos jurídicos ostentam diferentes planos de projeção e desenvolvimento. Pontes de Miranda encontra três traçados diversos, em sua clássica “escada pontiana”. São os planos da existência, da validade e da eficácia.

O plano da existência é o plano do ser. Revela exclusivamente a realização do suporte fático determinado pela norma.

Ainda, "no plano da existência não se cogita de invalidade ou eficácia do fato jurídico, importa, apenas, a realidade da existência. Tudo, aqui, fica circunscrito a se saber se o suporte fático suficiente se compôs, dando ensejo à incidência". (MELLO, 2007, p. 83).

O plano da validade pressupõe o da existência, sequenciando-o. Diz respeito ao momento em que o Direito perfaz uma triagem acerca da perfeição do ato, sob a perspectiva da ocorrência de um defeito invalidante.

Importa pontuar uma particularidade: "A invalidade - da qual são graus distintos a nulidade e a anulabilidade - estará condicionada à constatação de uma 'deficiência de elementos complementares do suporte fático relacionados ao sujeito, ao objeto ou à forma do ato jurídico"”. (MELLO, 2007, p. 97).

Sujeito este pois, que age segundo uma dada forma, tendo algo por objeto.

Por final, o plano da eficácia refere-se à parte do universo jurídico na qual os fatos produzem seus efeitos. Se repercute ou não no meio social. Trata-se da produção da juridicidade do fato jurídico. (MIRANDA, 1983 apud DINIZ).

Interessa-nos enfim, a delimitação entre aquilo que se tem por nulo e aqueloutro, anulável.

Pontes de Miranda explicitava tal distintivo de peculiar maneira. Veja: "o sentido adequado de relatividade e de absolutidade é o referente aos limites subjetivos da eficácia: relativa é a eficácia só atinente a um, ou a alguns, absoluta, a eficácia erga omnes". (MIRANDA apud DARCIE, 2011, p. 105).

Repelia, por conseguinte, o senso comum que centra a desigualdade da nulidade absoluta e relativa na parte que pode objetar o vício com demonstração de prejuízo, no instante processual preclusivo e na possibilidade ou não de saná-la.

E não é outra a ilação advinda dos Mestres Ada Grinover, Antonio Magalhães e Scarance Fernandes em recente conferência sobre o tema "Garantias Constitucionais e Nulidades Processuais":

A distinção clássica entre nulidade absoluta e nulidade relativa (prejuízo presumido ou prejuízo a ser demonstrado, reconhecimento de ofício e necessidade de arguição) está superada. 
O que vale é o interesse preservado pela norma: se se trata de interesse público, sua violação constitui nulidade absoluta; se se trata de um interesse das partes, fala-se de nulidade relativa.

As normas constitucionais que cuidam das garantias são de interesse das partes, mas sobretudo, de interesse do processo justo (e o juiz se legitima - não pelo voto - na medida que observa tais garantias - devido processo legal). A transgressão às normas constitucionais gera ou a nulidade absoluta ou o ato inexistente (porque todas as normas constitucionais são de interesse público (grifo nosso). (GOMES, 1993, p. 2).

Ainda:

Aliás, de fato, a dicotomia nulidade absoluta $x$ nulidade relativa se inicia com um injustificável equívoco. Ambos os conceitos são geralmente oferecidos pela doutrina a partir das características que uma e outra categoria possuiriam. Para dar um exemplo comezinho, é comum encontrar-se definições de nulidade relativa a partir da seguinte estrutura semântica: "nulidade relativa é aquela que não pode ser declarada de ofício pelo magistrado, que está sujeita à preclusão e à convalidação, que depende da demonstração de prejuízo, tendo em vista que regula interesse meramente privado das partes". A nulidade absoluta seria o anverso destas características. O primeiro grave erro é a definição de um instituto pelas suas características: retirando a categoria "interesse meramente privado" da definição, o conceito se esvazia por completo. (GLOECKNER, 2014, p. 15).

O que se está a argumentar é que a violação da forma de um ato processual cujo objetivo maior é estar em consonância ao Devido Processo Legal consolida vício absoluto, de sanação impossível.

E daí, tem-se que:

(...) as formas prescritas pela lei processual possuem uma inegável e precípua função de garantia em face do poder estatal. Neste horizonte compreensivo, quaisquer defeitos relativos à forma constituirão interesse de ordem pública, e terão, por conseguinte, dignidade para uma impugnação por um amplo rol de legitimados, uma vez que as garantias asseguradas pela forma inobservada representam (...) um direito constitucional e fundante do Estado Democrático, pertencente à sociedade como um todo (...) (grifo nosso). (DARCIE, 2011, p. 105).

Inclusive, para ilustrar o que se prega, agora numa exposição histórica sobre nulidades. 
Pois bem, inicio com a advertência de Pimenta Bueno neste ínterim, diante do processo, sobretudo o criminal, que mais nos interessa e se assemelha:

Quem não conhece bem o processo criminal, e portanto o valor das formas estranha que se mude um processo só por omissão delas; mas quem reconhece que sem a sua fiel observância o processo pode tornar-se um caos ou objeto de capricho e arbitrariedade dos juízes não pode pensar assim. Se o processo criminal fosse entregue à vontade dos Tribunais, a Justiça marcharia sem rumo certo ao acaso ou discrição do juiz. (PIMENTA BUENO apud GALLI, 1967, p. IX).

Por consequência, não se trata de preciosismo a nulificação processual em razão do desrespeito à forma.

Se se quer tomar a história como referência, importa não olvidar que a existência das nulidades ditas absolutas foi banida na Itália, que serve de norte para nosso país neste tema, quando do Código Rocco, leia-se, era fascista. Sendo felizmente restauradas em prol do ius libertatis imediatamente depois. (GALLI, 1967, p. X).

De fato, a disciplina das nulidades desde o Código de Processo do Império até os dias hodiernos acaba por restar em mãos dos julgados dos Tribunais, não havendo regramento legal para discernir entre nulidades e demais vícios processuais. (GALLI, 1967, p. IX).

Não se despreza, contudo, que o tópico das nulidades constitui-se como um daqueles nos quais doutrina e jurisprudência tem posicionamentos discrepantes.

Pesquisa empírica nesta acepção das nulidades processuais foi conclusiva demonstrando como o processo assinala-se como instrumento fundamentalmente persecutório, raramente protetivo dos imputados, com consequências nefastas à estrutura de garantias constitucionais. (CARVALHO; LOUREIRO, 2009, p. 512).

Algumas conclusões numéricas:

- "discrepância entre as nulidades suscitadas e as nulidades efetivamente declaradas";

- "certa tendência de os Julgadores entenderem o pleito defensivo como estratégia na busca de vantagem processual desleal, artimanha para tangenciar a imputação e retardar a decisão";

- "a maior alegação de falha processual provém do descumprimento de prescrição legal”; 
- "dentre os argumentos das decisões judiciais repelindo as nulidades, ${ }^{1}$ tem-se, violação formal inexistente, violação formal com ausência de prejuízos e mérito favorável". (CARVALHO; LOUREIRO, 2009, p. 511-533).

A ilação do estudo é que existe incontestável deficit no sistema pátrio das nulidades processuais, com tradição jurídica da prática processual arraigada numa lógica inquisitiva em contraponto à axiologia inovadora da Constituição da República.

E prosseguindo, a premissa de que se deve validar um determinado ato processual ainda que em desconformidade aos ditames processuais porque alcançou a finalidade, teve eficácia ou efetividade processual, resulta em patente inabilidade dos planos exibidos pelo Catedrático Pontes de Miranda, num perverso menosprezo dos elementos primordiais de qualquer procedimento, com supressão de direitos e garantias dos cidadãos envolvidos.

Neste ínterim, agrega-se a nefanda desinteligência da demonstração do prejuízo para nulificação. A comprobação do dano é um encargo do qual duramente irá, qualquer um, se tanto, desincumbir-se.

Na lição de Lopes Jr., em verdade, é 'uma fraude processual a serviço do punitivismo'. Observe:

(...) além da imprecisão em torno do que seja prejuízo, há um agravamento no trato da questão no momento em que se exige que a parte prejudicada (geralmente a defesa, por evidente) faça prova dele. Como se faz essa prova? Ou ainda, o que se entende por prejuízo? Somente a partir disso é que passamos para a dimensão mais problemática: como demonstrá-lo? (LOPES JR., 2009, p. 421).

Enfim, como fazer a prova do impossível? Tal aspecto foi argutamente enfatizado pelo Ministro Sepúlveda Pertence, embora em julgamento processual penal, de seguinte alvo: nulidade decorrente de falta de notificação do defensor técnico para sessão de julgamento do recurso.

Isto é, como provar que se o caso tivesse sido conduzido de outra maneira, diverso seria o resultado? Atente:

\begin{abstract}
Sustentação oral frustrada pela ausência de intimação da pauta de julgamento: demonstração do prejuízo: prova impossível. Frustrado o direito da parte à sustentação oral, nulo o julgamento, não cabendo reclamar a título de demonstração de prejuízo, a prova impossível de que, se
\end{abstract}

Também, saneamento sem anulação, vício não suscitado pela acusação, instrumento inadequado, torpeza da parte, preclusão, insignificância. 
utilizada aquela oportunidade legal de defesa, outra teria sido a decisão do recurso. (STF, $1^{\mathrm{a}}$ T., HC 85443-SP, 2005).

Além do mais, mister fazer referência de que, a mostra do prejuízo para nulificação cuida-se de requisito de origem napoleônica do Antigo Regime, pas de nulité sans grief, que presta-se como o maior argumento para a não decretação de nulidade. Linhagem mais que razoável para alijá-lo do sistema democrático constitucional hodierno.

De tal modo: "Basta por consiguiente que la excepción de nulidad encuentre en la ley su justificación y atienda a la condición procesal de la parte excepcionante, aunque no se demuestre que haya experimentado ella un perjuicio efectivo". (SCHIFFRIN, 2001, p. 435).

Não se está a afirmar que o mero desrespeito à forma seja o valor absoluto a ser salvaguardado, mas sim o que sustenta a forma prescrita, isto é, toda a valoração que o legislador fez no instante da imposição daquela especial forma.

Noutras palavras, o prejuízo resulta do próprio descumprimento da forma, que assim elegeu o legislador, e nunca, o julgador!

Tomar em outro sentido seria negar a ocorrência do prejuízo em si mesmo. Lendo-o pois, dentro de uma cultura inquisitiva, que passa ao derredor dos valores constitucionais, acrescida da deformidade operada pelos julgadores de que a carga da prova do prejuízo carrega ao imputado, olvidando, o óbvio, de que, “em inúmeros casos a demonstração é impossível, pois, o dano às garantias formais e substanciais nem sempre deixa vestígios materiais apreensíveis (...)". (CARVALHO; LOUREIRO, 2009, p. 530). Note:

Com efeito, no que diz respeito ao prejuízo, é necessária radical inversão do pensamento, pois, atribuir o ônus da comprovação ao acusado consiste em distorcer o sistema para satisfação da estabilidade do trâmite e não dos princípios constitucionais. Obrigar o acusado a comprovar o prejuízo equivale a negar vigência ao interesse danificado. Outrossim, a lógica que deve imperar é a da presunção de prejuízo (...). (CARVALHO; LOUREIRO, 2009, p. 531).

A ruptura da forma legal instituída para um ato processual funciona como um sinal de que houve transgressão de um princípio, a deprecar atividade saneadora daquele que conduz o processo. (RAMALHO JÚNIOR, 2008, p. 90).

Ao ordenar uma definida forma da qual deve blindar o ato jurídicoprocessual, o tipo processual (fattispecie) adota um código assegurador das garantias constitucionais do sistema processual, posta depois de uma avaliação de valores antecipadamente indicada pelo legislador. Alerta-se:

A forma estabelecida para o ato processual (fattispecie), portanto, visa a assegurar a máxima otimização dos 
princípios constitucionais, possuindo uma pretensão de decidibilidade no conflito entre tais valores. A violação da forma, em um tal horizonte compreensivo, poderá conduzir ao desequilíbrio da ponderação já estabelecida pelo legislador, daí resultando uma mitigação não autorizada da eficácia dos princípios constitucionais que assistem ao indivíduo. (DARCIE, 2011, p. 111).

Destarte, alcançamos relevante ponto desta contenda.

Um escólio impõe-se: a nulificação absoluta é imperiosa e independente da satisfação dos participantes e do fim do ato. ${ }^{2}$ (BORREGO, 1998, p. 105-145).

$\mathrm{E}$, de novo, aprofundando nestes conceitos, mister pensar que toda esta narrativa conflui para o respeito ao Devido Processo Legal ${ }^{3}$ que tem a vertente inafastável da Defesa Ampla, que se contrapõe metodologicamente e gramaticalmente a uma inconcebível Defesa Restrita (e não, Defesa ineficiente ou não efetiva) com supressão de quaisquer faculdades processuais e, por conseguinte, amostra de nulificação absoluta por desobediência a garantias constitucionais.

Recomendável a depuração dessa confusão conceitual pelo uso de somente dois juízos: o de defesa ampla - o qual atende a exigência contida no art. $5^{\circ}$, inciso LV da Carta Política ${ }^{4}$ - e o de defesa restrita (antítese daquela), o qual enseja uma nulidade processual por motivo de violação à sobredita garantia constitucional.

Prosseguindo:

(...) é lícito aduzir que o seu desrespeito enseja sempre a nulidade absoluta do processo judicial, por atipicidade constitucional. Não há portanto, como se cogitar de nulidade relativa ou de mera irregularidade, em razão da dimensão de garantia que tem o preceito constitucional em apreço, por interessar à ordem pública e à boa condução do processo (grifo nosso). (MALAN, 2006, p. 268).

2 "Qué ocurriría si un juez civil dictase un auto de detención, y el acusado por ignorancia no formula el correspondiente recurso de invalidez? Acaso este tipo de actuación tiene plena validez a propósito de la competencia objetiva en cuanto a la materia? Aquí prevalecen las normas de orden público y se propone un correctivo a fin de que todo lo actuado en desmedro de los presupuestos procesales tenga que ser preservado, independientemente del fin del acto y si todos los participantes estén satisfechos". (cf. p. 123).

3 Art. $5^{\circ}$ da Constituição Federal:

(...)

LIV - ninguém será privado da liberdade ou de seus bens sem o devido processo legal;

4 Art. $5^{\circ}$ da Constituição Federal:

(...)

LV - aos litigantes, em processo judicial ou administrativo, e aos acusados em geral são assegurados o contraditório e ampla defesa, com os meios e recursos a ela inerentes; 
Neste ínterim, convém apontar imprecisão corriqueiramente sucedida na seara do processo, qual seja, a reserva da expressão inexistência para casos de violação de normas constitucionais e, assim, esvaecimento da categoria nulidades absolutas, restando qualquer outra violência num patamar de indispensabilidade de comprovação de prejuízo, qual seja, da categoria nulidade relativa.

Aliás, é disto que se está afinal, a cuidar na hipótese do presente.

E, perceba que, retornando a lição do Mestre Pontes de Miranda, inexistência está para além deste parâmetro, sendo em realidade, uma espécie de não ato.

Assim, deve-se ter em cuidado discurso flexibilizador que se opõe ao formalismo e que, converte-se afinal, "em artifício retórico para o exercício e o abuso de poder” (grifo nosso). (CARVALHO; LOUREIRO, 2009, p. 514). Também:

$O$ sistema de nulidades é o respiradouro das garantias fundamentais. De nada adianta um rol infindável de direitos e garantias fundamentais se admissíveis (através do saneamento) as mais variadas formas de sua transgressão. Os efeitos da declaração de invalidade não podem ser pensados como facultativamente ligados ao "querer" do julgador. Sendo a invalidade uma declaração, a ineficácia do ato processual é a sua consequência necessária (e não acessória...). Prejuízo e instrumentalidade das formas são categorias preexistentes à Constituição da República e para além disso, vitais para a constituição dos sistemas neoinquisitoriais contemporâneos, que se caracterizam, dentre outros aspectos, pela desformalização progressiva das formas e pelo esvaziamento das garantias processuais. (GLOECKNER, 2014, p. 15).

Sopesando todas as exposições prévias, tem-se, mais uma vez, a inteligência de que a situação aventada, qual seja, a oralidade erigida em primazia em Processo Administrativo Disciplinar, redunda em insanável nulidade, cujo deslinde é o refazimento dos atos processuais maculados e consequentes, mesmo porque no processo $\mathrm{o}$ ato maculado não se encontra isolado, mas interligado. Advirta:

(...) concatenazione causale che, al pari di quanto avviene in qualsiasi fattispecie complessa a formazione progressiva, percorre l'intera fattispecie processuale, in guisa che l'atto antecedente si ponga come pressupposto del successivo, fa si che, in caso di declaratória de nulittà del primo, tutti i successivi siano destinati a cadere. (TAORMINA, 1995, p. 424). 


\subsection{Alegações Finais e Relatório Final no Processo Disciplinar}

Nomeadamente no que concerne à hipótese cogitada, uma vez encerrada a instrução probatória, as Alegações Finais ofertadas verbalmente, sequenciada de igual forma pelo Relatório Final, ostenta no procedimento Nulidade de cunho Absoluto, tudo em dissensão aos ditames legais e constitucionais para a espécie.

Mister salientar que, o processo administrativo disciplinar é o "instrumento formal, instaurado pela Administração Pública, para a apuração das infrações e aplicação das penas correspondentes aos servidores, seus autores". (GASPARINI, 1995, p. 561-563, p. 572-573).

Assim, o processo administrativo disciplinar, como toda a manifestação de vontade da Administração Pública, sofre a influência não só dos princípios constitucionais previstos expressamente no caput do art. 37 (Legalidade, Impessoalidade, Moralidade, Publicidade e Eficiência), quanto também, como gizado alhures, dos princípios da Ampla Defesa, do Contraditório e do Devido Processo Legal, indicados no art. $5^{\circ}$, incisos LIV e LV, dessa mesma Carta Política. E, se de verdade já incontestável que no procedimento administrativo vige o Devido Processo Legal (art. 5 , inciso LV da Constituição da República), tal se traduz no asseguramento de direitos ao inculpado, inclusive no que concerne à forma procedimental. ${ }^{5}$

Assim, permitir a manifestação oral do Defensor ou mesmo respaldála, com sucessivo Relatório igualmente oral, sob a vestimenta de argumento de que tal expressa o contraditório, é, mais uma vez, repita-se até a exaustão, violar as chamadas garantias procedimentais contidas na cláusula do Devido Processo Legal, uma vez que inexiste qualquer previsão legal neste sentido.

Se toda a alegação teórica supra não for o suficiente, convém salientar, do ponto de vista prático, a relevância da peça Alegações Finais.

Noutros termos, as Alegações Finais traduzem o instante decisivo e culminante de toda a atividade defensiva ao longo do procedimento, podendo autorizar a nulificação se maculada:

(...) não se pode conceber alegações finais que sejam destituídas de (i) fundamentação jurídica minimamente consistente e plausivel, preferencialmente baseada em citações doutrinárias e jurisprudenciais; (ii) análise dos

\footnotetext{
5 Em outras palavras, em termos de adesão ao conhecido modelo garantista de democracia constitucional proposto por Luigi Ferrajoli, um sistema jurídico está escorado em duas órbitas de sólidos princípios constitucionais substanciais (penais) e instrumentais (processuais) com uma notória relação de reciprocidade (biunívoca) entre as duas esferas de garantias, que valem não somente por si mesmas, isoladamente, mas também, conjuntamente, como garantia recíproca de sua efetividade.
} 
elementos de prova contidos nos autos; (iii) pedido de absolvição do acusado (grifo nosso). (MALAN, 2006, p. 267).

E, não se pode olvidar que, toda a atividade da Administração Pública e, consequentemente, dos seus agentes, deve ser exercida em conformidade com a lei. ${ }^{6}$

Mais especificamente, ver a Lei Complementar n. 942, de 6 de junho de 2003, que alterou a Lei n. 10.261, de 28 de outubro de 1968, que regia Estatuto dos Funcionários Públicos Civis do Estado de São Paulo:

Artigo 292 - Encerrada a fase probatória, dar-se-á vista dos autos à defesa, que poderá apresentar alegações finais, no prazo de 7 (sete) dias.

Parágrafo único - Não apresentadas no prazo as alegações finais, o presidente designará advogado dativo, assinandolhe novo prazo.

Artigo 293 - O relatório deverá ser apresentado no prazo de 10 (dez) dias, contados da apresentação das alegações finais.

$\S 1^{\circ}-\mathrm{O}$ relatório deverá descrever, em relação a cada acusado, separadamente, as irregularidades imputadas, as provas colhidas e as razões de defesa, propondo a absolvição ou punição e indicando, nesse caso, a pena que entender cabível.

$\S 2^{\circ}$ - O relatório deverá conter, também, a sugestão de quaisquer outras providências de interesse do serviço público.

ARTIGO 300 - TERÃO FORMA PROCESSUAL RESUMIDA, QUANDO POSSÍVEL, TODOS OS TERMOS LAVRADOS PELO SECRETÁRIO, QUAIS SEJAM: AUTUAÇÃO, JUNTADA, CONCLUSÃO, INTIMAÇÃO, DATA DE RECEBIMENTO, BEM COMO CERTIDÕES E COMPROMISSOS.

$\S 1^{\circ}$ - Toda e qualquer juntada aos autos se fará na ordem cronológica da apresentação, rubricando o presidente as folhas acrescidas.

$\S 2^{\circ}$ - Todos os atos ou decisões, cujo original não conste do processo, nele deverão figurar por cópia. (grifo nosso).

6 Art. $5^{\circ}$. Inciso II da Constituição da República:

(...)

II - ninguém será obrigado a fazer ou deixar de fazer alguma coisa senão em virtude de lei; 
Vale neste ínterim, recordar que, nos moldes da previsão constitucional e da legislação regente, o processo caracteriza-se como um conflito disciplinado e dialeticamente ritualizado. Para sanar a desigualdade substancial entre os sujeitos nele envolvidos desigualdade esta potencializada no âmbito punitivo, em que, de um lado, tem-se o aparelho estatal de persecução e, de outro, o indivíduo que arrisca ser submetido a uma pena pública, a quem cabe reagir à imputação proposta, nos limites de sua hipossuficiência, são garantidos, pois, o direito de se informar quanto ao conteúdo da acusação (contraditório) e o direito de contradizer a imputação (exercício de defesa). (BRASIL, 2012, p. 1.549).

Destarte, a determinação de um rito procedimental propende a resguardar precisamente a capital contradição dialética do processo, tão imperativa para o julgador erigir seu aforismo.

Ainda, mister realçar em ocorrência assemelhada que:

A interpretação do STF ratifica procedimento que tem se tornado corriqueiro nos Juízos de primeira instância e que fere, com único ato, os princípios do contraditório (reserva de informação), da ampla defesa (ausência de oportunidade para a contradição) e do devido processo legal (atipicidade formal). Trata-se, pois, de ato processual que dá causa a nulidade absoluta porque viola princípios fundamentais do processo penal. De acordo com Eugênio Pacelli (Curso de Processo Penal. 15. ed. Rio de Janeiro: Lumen Juris, 2011. p. 696), esses vícios processuais que decorrem de nulidade absoluta referem-se ao processo penal como função jurisdicional, pondo em risco a própria função judicante, com reflexos irreparáveis na qualidade da jurisdição prestada. (BRASIL, 2012, p. 1.549).

Reforça esta concepção, a noção de que tais atos processuais não interessam tão só às partes diretamente interligadas, mas outros interessados que tomarão acesso ao processo. E, nesta hipótese surge o Relatório Final que expõe valor intrínseco para o julgamento a ser finalizado pela autoridade competente da Administração Pública.

Deste modo, a obrigatoriedade de um perfeito relatório não se trata de mera imposição legal, mas sim, obediência a uma noção da relevância, em primeiro, de um instrumento técnico processual que permita às partes envolvidas avaliarem o conteúdo do exposto e compreenderem melhor os fundamentos da decisão. Possibilita, ainda, a percepção de forma individualizada do objeto da inculpação. Sendo um relatório vicioso autêntico obstáculo ao exercício do direito ao contraditório, pela parte que se julgar lesada, na medida em que enfrentará dificuldades para aduzir adequadamente às razões de seu recurso. 
Contudo, deve-se fazer menção à relevância maior, qual seja, o detalhamento do sucedido no procedimento disciplinar para a autoridade julgadora final, a qual enfrentará dificuldades para visualizar os raciocínios que levaram o Relator a sugerir tal ou qual medida, embaraçando o próprio andamento do referido processo.

Assim, de novo, deverá constar da peça derradeira dados e elementos suficientes para que a autoridade julgadora compreenda todo o desenrolar dos fatos sob investigação. Ostenta, portanto, função que refoge ao simples convencimento de seu prolator.

Além do especificado acima quanto ao Estatuto Funcional no âmbito bandeirante e seu versículo 293, tem-se como um rol dos elementos que deverão constar da peça em comento, essenciais para um Relatório Final satisfatório:

a) resumo dos fatos sob apuração;

b) breve relato das medidas adotadas pela Comissão no sentido de investigar o caso, inclusive informações relacionadas às oitivas de testemunhas e interrogatórios;

c) relação de eventuais exames periciais e suas respectivas conclusões;

d) elementos detalhados sobre os indiciamentos, caso tenham ocorrido;

e) RAZÕES APRESENTADAS NA DEFESA ESCRITA e as respectivas considerações sobre cada uma delas;

f) conclusão pela inocência ou culpa dos servidores envolvidos e, no caso de responsabilização, sugestão de penalidade a ser aplicada, levando-se em consideração a natureza e a gravidade da infração cometida, os danos que dela provieram para o serviço público, as circunstâncias agravantes ou atenuantes e os antecedentes funcionais (art. 128 da Lei n. 8.112/90);

g) eventuais encaminhamentos necessários, como, por exemplo, Controladoria-Geral da União, Advocacia-Geral da União, Tribunal de Contas da União e Ministério Público Federal;

h) possíveis medidas administrativas a serem adotadas com o propósito de evitar futuras ocorrências de fatos da mesma natureza no órgão. (grifo nosso). (CONTROLADORIAGERAL DA UNIÃO, 2016).

E tornando, neste aspecto, o Relatório escrito tem fundamental prestígio na medida em que a decisão final, como ato de comunicação, necessita conter uma 
racionalidade, devendo esta não apenas ser exprimida, mas corroborada, mediante um discurso bem arquitetado em termos redacionais. ${ }^{7}$

Ora, para que prestaria o Relatório senão "relatar" de maneira completa para outrem julgar?

Esquece-se o Douto Procurador do Estado Presidente do Processo Disciplinar de que a autoridade final para decisão é o Senhor Secretário de Estado da Administração Penitenciária e não ele?

Como sopesar tudo com perfeição se simplesmente não há a argumentação derradeira da Defesa e seu rogo, deformalizada em enxutas Alegações Finais também verbais?

Aliás, quanto à aparência redacional supracitada, mister referir que não se ignora o conteúdo semântico das palavras concisão ${ }^{8}$ e extensão. ${ }^{9}$

O que se está a advogar, em verdade, não é a prolixidade, o enfadonho, a redundância, o pleonasmo, mas a inegável vigilância de não omitir absolutamente nada em prol de uma falaciosa otimização que não socorre senão o processo e seu condutor, violando as garantias constitucionais e legais do interessado.

Conciso é sim, aquele que oferta toda a informação em número preciso de palavras sem nunca comprometer a exatidão.

De sabença, num texto igualmente são postuladas, correção, elegância, compreensão, lógica e entrosamento entre ideias.

Devemos abrir mão de todas estas qualidades em prol da celeridade? Ou como se exora em prol da Economia Processual e da Duração Razoável do Processo?

E, mesmo que para alguns, a resposta fosse afirmativa, ainda nos sustenta a legalidade e constitucionalidade que obstaculiza tal resolução.

Não se pode olvidar que, o procedimento disciplinar tem natureza sancionatória e, de acordo com a esfera administrativa, ritos bem delimitados, ad exemplum, o contido na legislação para funcionalismo federal. ${ }^{10}$

7 E, mutatis mutandis: “... a decisão judicial adequadamente fundamentada não objetiva tão-somente adequarse ao ordenamento jurídico em termos de validade, mas significa, também, um exercício de persuasão que magistrado realiza, de forma a convencer aos destinatários de sua decisão que esta é a melhor solução que se poderia alcançar.” Disponível em: <http://jus.com.br/artigos/14333/principio-da-motivacao-das-decisoesjudiciais-como-garantia-constitucional>. Acesso em: 4 dez. 2013.

8 BREVIDADE E CLAREZANO DIZER OU ESCREVER. Disponível em: $<$ http://www.dicionariodoaurelio. com/concisao>. Acesso em: 5 jan. 2015.

9 ATO DE TORNAR EXTENSIVA A SIGNIFICAÇÃO DE UMA PALAVRA. Disponível em: < http://www. dicionariodoaurelio.com/extensao>. Acesso em: 5 jan. 2015.

10 Na Administração Pública Federal, o processo administrativo disciplinar tem como base legal a Constituição Federal, que veio a ser regulamentada pela Lei n. 8.112/90, em seus Títulos IV (do Regime Disciplinar, arts. 116 a 142) e V (do Processo Administrativo Disciplinar, arts. 143 a 182). Entretanto, a Lei n. 8.112/90 apresenta algumas lacunas relativas ao processo administrativo disciplinar que demandam integração por 
E pois, no que concerne à diversidade de ritos: Sumário e Ordinário. Todavia, tal não se depreende na esfera em debate.

$\mathrm{O}$ rito sumário, não previsto inicialmente quando da publicação da Lei n. 8.112, de 11/12/1990, foi acrescido posteriormente com a alteração promovida pela Lei n. 9.527, de 10/12/1997. Assim, após esse disciplinamento legal, pode-se concluir que o processo administrativo disciplinar passou a admitir três espécies: sindicância acusatória (art. 145, inciso II), processo disciplinar ordinário (art. 146) e processo disciplinar sumário (arts. 133 e 140). Saliente-se que o novel rito é aplicável apenas quando da apuração dos seguintes ilícitos administrativos: acumulação ilegal de cargos, abandono de cargo e inassiduidade habitual. Em linhas gerais, o rito sumário possui as seguintes especificidades: os prazos são reduzidos em relação ao rito ordinário e a portaria de instauração deve explicitar a materialidade do possível ilícito. (CONTROLADORIAGERAL DA UNIÃO, 2016).

Afinal, não é por outra justificativa que na Lei de Ação Popular, a forma seja móvel o bastante para nulificar o ato quando transmutada. ${ }^{11}$

Veja o que dispõe a Lei n. 4.717, de 29 de junho de 1965:

Art. $2^{\circ}$ São nulos os atos lesivos ao patrimônio das entidades mencionadas no artigo anterior, nos casos de:

b) vício de forma;

E, com fulcro no expendido, vale sublinhar, de novo, que se trata enfim, de Nulidade Absoluta que não se sujeita a qualquer demonstração de prejuízo para ver-se presente. ${ }^{12}$

meio de outras legislações aplicáveis, com destaque para as seguintes:

a) Lei n. 9.784/99 (Lei de Processo Administrativo) - regula o processo administrativo no âmbito da Administração Pública Federal. A aplicação das regras elencadas na Lei Federal n. 9.784/99 aos processos administrativos disciplinares (regidos por lei especial - Lei n. 8.112/90) será subsidiária, vale dizer, a lei geral incidirá nas partes omissas e sempre que não houver disposição especial no Estatuto dos Servidores Públicos Federais, como prevê o art. 69;

b) Lei n. 8.429/92 (Lei de Improbidade Administrativa) - além de trazer disposições para responsabilizar agentes públicos por atos de improbidade, agrega aspectos específicos para o processo administrativo disciplinar, definindo os atos de improbidade administrativa e cominando penas passíveis de serem aplicadas a agentes públicos.

Disponível em: < http://www.cgu.gov.br/publicacoes/guiapad/Arquivos/Manual_de_PAD.pdf>. Acesso em: 4 dez. 2013.

11 De mesma inteligência, os diplomas infraconstitucionais aplicáveis subsidiariamente à temática, isto é, o Código de Processo Penal e o Código de Processo Civil.

12 Direito Processual Penal. Tráfico internacional de drogas/entorpecentes. Nulidade insanável. Defesa preliminar. Inobservância do procedimento legal. Nulidade por ofensa aos princípios constitucionais. Princípio do contraditório. Princípio da ampla defesa. “(...) I - Hipótese na qual ao apelante foi imputada a prática do crime de tráfico de entorpecentes, cuja denúncia foi recebida sem que o juízo lhe possibilitasse 
De tal modo, uma vez vislumbrada a nulidade absoluta, há o comprometimento integral da validade do feito face à natureza e gravidade da ilegalidade. Os atos perpetrados sob este defeito não geram efeitos jurídicos, sendo-lhes vedada a convalidação. Ademais, ante o efetivo prejuízo à defesa, não é requerida a demonstração da ofensa provocada ao inculpado (presunção absoluta). Da mesma maneira, a invalidade poderá ser arguida por qualquer interessado, no curso ou após a conclusão do processo, não incidindo os efeitos da preclusão à espécie.

Por conseguinte, independe seu reconhecimento mesmo com sugestão inicial de absolvição do acusado (leia-se, precária, porque não acatada ainda, pela autoridade julgadora).

\section{Leciona José Armando da Costa:}

As nulidades absolutas são aquelas que, afrontando o rito de concretização do ato processual, traduzem patente prejuízo para o acusado, ou trazem, por força de lei ou regulamento, a presunção juris et de jure dessa ofensa. Em razão dessas proeminências, não carecem essas nulidades de demonstração de prejuízo por parte do interessado. (COSTA, 2011, p. 437).

Preservar a formalidade legal é inclusive, entender que o processo deve ficar resguardado de eventuais futuras ações judiciais que aleguem o não exercício pleno do contraditório e da ampla defesa.

Deste modo, parece-nos que tal procedimento ocorre ao largo dos parâmetros legais, sendo a nulificação fundamentada, a partir da apresentação das Alegações Finais em Debates, inclusive.

Capítulo a parte é aquele que toca à incidência do Informalismo Moderado.

a apresentação de defesa preliminar. II - Inobservância do procedimento previsto no art. 55 da Lei n. 11.343/06, que gera nulidade absoluta, e prescinde da demonstração de prejuízo, por violação aos princípios constitucionais da ampla defesa e do devido processo legal. III - Preliminar acolhida para anular a ação penal, desde o recebimento da denúncia, prejudicada a apelação do Ministério Público Federal. (...).” (TRF 3. ${ }^{\mathrm{a}} \mathrm{R}-1$ a $^{\mathrm{a}}$ T. - AP 2008.61.19.010161-1 (0010161-45.2008.4.03.6119) - rel. José Lunardelli - j. 19.4.2011 - public. 5.5.2011);

Direito Processual Penal. Habeas corpus. Defesa preliminar. Recebimento da denúncia. Inobservância de procedimento legal. Nulidade ab initio. "I - A impetração tem como fundamento a inobservância do rito processual previsto no art. 38 da Lei n. 10.409/02 (defesa preliminar), a consubstanciar nulidade processual absoluta, dado que ao paciente não foi dada oportunidade de oferecer defesa preliminar. II - A jurisprudência do Supremo Tribunal Federal está alinhada no sentido de que a inobservância do rito processual fixado no art. 38 da Lei n. 10.409/2006 é causa de nulidade absoluta (omissis). Defiro a ordem para anular a ação penal desde o recebimento da denúncia e determinar que o paciente seja posto imediatamente em liberdade, se por al não estiver preso." (STF - 2. ${ }^{\mathrm{a}}$ T. - HC 99.720 - rel. Eros Grau - j. 1.6.2010). 
Pois bem, haveria em face das aludidas garantias, interpretação que aflora, com uma nomenclatura própria, no que nos interessa, a regra fundamental do Informalismo Moderado.

O princípio do informalismo ou do formalismo moderado está sim expressamente previsto, como no art. 22 da Lei Federal n. 9.784, de 29 de janeiro de 1999, cujo teor é o seguinte:

Os atos do processo administrativo não dependem de forma determinada senão quando a lei expressamente a exigir.

Diz-se que a inspiração do legislador federal partiu das disposições do art. 154 do Código de Processo Civil: "Os atos e termos processuais não dependem de forma determinada senão quando a lei expressamente a exigir, reputando-se válidos os que, realizados de outro modo, lhe preencham a finalidade essencial".

Noutros termos, há dispensa de formas rígidas salvo se expressas em lei ou garantidoras dos Direitos do Processado.

E, ainda, adverte-se que o informalismo não pode servir de pretexto para a existência de um processo administrativo defeituosamente estruturado e pessimamente constituído, em que não se obedeça à ordenação, à cronologia dos atos praticados, à certeza jurídica e à segurança procedimental. (GASPARINI, 1995, p. 561-563).

Há, por conseguinte, uma concepção de indisponibilidade do rito, que independe de consentimento das partes envolvidas, redundando quando em seu desrespeito numa nulidade processual insanável.

Na hipótese sub examine, faz-se menção ao todo já do discorrido neste artigo, que repele integralmente tal fundamento, para não se tornar repetitiva, mormente a falaz diretriz de que se deve regularizar um determinado ato processual ainda que em desconformidade aos regramentos processuais porque alcançou a finalidade, teve eficácia ou efetividade processual, procedente de equívoco intolerável diante dos cortes fundantes de qualquer procedimento ou processo, com banimento de direitos e garantias dos cidadãos envolvidos. Considere:

(...) afirmando que o princípio da instrumentalidade das formas é a viga mestra do sistema de nulidades - e que, portanto, o prejuízo deve ser demonstrado em qualquer uma das espécies de invalidades - acaba não apenas por tornar indistinguíveis as categorias (nulidade relativa e absoluta) como por torná-las, à luz da usual caracterização doutrinária, nulidades relativas. A exigência de demonstração de prejuízo na arguição de nulidade absoluta (aquela cujo prejuízo é presumido) demonstra não apenas a falibilidade da classificação tradicional das nulidades mas também expõe a suscetibilidade da forma processual (...) às culturas acusatória e inquisitória. (GLOECKNER, 2014, p. 15). 
Encerra-se por fim, com a máxima que principia o Livro 29 da grande obra "Espírito das Leis" de Montesquieu: "As formalidades da justiça são necessárias à liberdade".

\section{Conclusão}

A importância deste artigo concentra-se na discussão sempre perene do respeito ao Devido Processo Legal e consequências quando maculado.

Presta-se igualmente para pontuar novel inteligência acerca da diferenciação entre nulidade absoluta e relativa, apreendendo o verdadeiro fulcro da distinção, qual seja, o interesse preservado pelo regramento e seu âmbito de alcance. Noutros termos, interesse público ou das partes.

E neste ínterim, encontra-se o sustento de todo o debate: o Devido Processo Legal, como norma constitucional, visa assegurar não apenas a segurança das partes, mas primordialmente um processo justo.

E por consequência evidente, se violado, estar-se-á, diante de nulidade absoluta.

Depreende-se que o tipo processual contém códigos de segurança devidamente sopesados pelo legislador. No caso em testilha, a axiologia constitucional.

Destarte, a excelente condução do processo é peso que interessa à ordem pública, e, por conseguinte, independe de demonstração de prejuízo, ainda mais quando se percebe a prova diabólica em que tal consiste.

Garantir direitos e impor cabal comprovação de lesão, nesta seara, é repelir toda a sistemática constitucional das nulidades. Ou por outro lado, entender a afronta às normas constitucionais como ato inexistente, além de sua inegável raridade, é extirpar do quadro, a figura das nulidades absolutas.

Não se olvide da práxis jurídica, que deformaliza o processo sob a batuta do Código do Julgador de plantão.

Não merece prosperar, contudo, tal encaminhamento eis que, por óbvio, o procedimento, e aqui se insere o Processo Administrativo Disciplinar, não interessa somente ao condutor do referido procedimento, mas principalmente a muitas outras figuras, dentre as quais, a autoridade julgadora final.

Desta maneira, concordar com atos processuais da grandeza das Alegações Finais ou, mormente, do Relatório Final, transmutados em enxutos resumos de digressões verbais, é colocar por terra todo o Devido Processo Legal.

Inviabilizando à autoridade julgadora final, amplo conhecimento do processado e, a partir disto, abrindo larga margem à posterior contestação judicial. 
A costumeira assertiva da Instrumentalidade das Formas ou do Informalismo Moderado arrepia a espinha do sistema das nulidades, convindo a um quadro realmente acusatório e inquisitivo.

São Paulo, março de 2016.

\section{Referências}

BADR, Eid. Princípio da motivação das decisões judiciais como garantia constitucional. Jus Navigandi, Teresina, ano 15, n. 2.415, fev. 2010. Disponível em: <http://jus.com.br/artigos/14333/ principio-da-motivacao-das-decisoes-judiciais-como-garantia-constitucional $>$. Acesso em: 4 dez. 2013.

BORREGO, Carmelo. Nulidades procesales en el proceso penal: estudio preliminar. In: BELLO RENGIFO, Carlos Simón; ROSALES, Elsie. Libro homenaje a José Rafael Mendoza Troconis. Caracas: Instituto de Ciencias Penales y Criminológicas. Facultad de Ciencias Jurídicas y Políticas. Universidad Central de Venezuela, 1998. 2 t. p. 105-145.

BRASIL. Supremo Tribunal Federal. Jurisprudência comentada. Boletim IBCCRIM, São Paulo, ano 20, n. 233, p. 1.549, abr. 2012. (Caderno de Jurisprudência). Disponível em: <http://www.ibccrim. org.br/boletim_artigo/4602-SUPREMO-TRIBUNAL-FEDERAL>. Acesso em: 4 dez. 2013.

BREDA, Antonio Acyr. Efeitos da declaração de nulidade no processo penal. Ciência Penal, Rio de Janeiro, v. 6, n. 2, p. 104-128, 1980.

CARVALHO, Salo de; LOUREIRO, Antônio Carlos Tovo. Nulidades no processo penal e Constituição: estudo de casos a partir do referencial garantista. In: PRADO, Geraldo (Coord.); MALAN, Diogo (Coord.). Processo penal e democracia: estudos em homenagem aos 20 anos da Constituição da República de 1988. Rio de Janeiro: Lumen Juris, 2009. p. 511-533.

CONCISÃO. In: DICIONÁRIO do Aurélio online. Disponível em: $<$ http://www.dicionariodoaurelio. com/concisao>. Acesso em: 5 jan. 2015.

CONTROLADORIA-GERAL DA UNIÃO. Manual de processo administrativo disciplinar. Disponível em: <http://www.cgu.gov.br/Publicacoes/atividade-disciplinar/arquivos/manual-pad. pdf $>$. Acesso em: 4 mar. 2016.

COSTA, José Armando da. Teoria e prática do processo administrativo disciplinar. 6. ed. Brasília: Brasília Jurídica, 2011.

COSTALUNGA, Danilo Alejandro Mognoni. A teoria das nulidades e o sobre direito processual. Revista dos Juizados Especiais, v. 3, n. 9, p. 19-47, jul./set. 1998.

DARCIE, Stephan Doering. Breves reflexões acerca das nulidades no processo penal. Revista Síntese de Direito Penal e Processual Penal, Porto Alegre, v. 11, n. 68, p. 99-116, jun./jul. 2011. 
DINIZ, Gustavo Saad. Existência, validade e eficácia do negócio jurídico estipulado por sociedade empresária. Disponível em: <http://myrtus.uspnet.usp.br/pesqfdrp/portal/professores/gustavo_s/ pdf/exist $\%$ C3\%AAncia.pdf $>$. Acesso em: 5 jan. 2015.

EXTENSÃO. In: DICIONÁRIO do Aurélio online. Disponível em: $<$ http://www.dicionariodoaurelio. com/extensao>. Acesso em: 5 jan. 2015.

GASPARINI, Diogenes. Direito administrativo. 4. ed. São Paulo: Saraiva, 1995.

GALLI, Ítalo. A disciplina das nulidades no código de processo penal. Julgados dos Tribunais de Alçada de São Paulo, São Paulo, n. 2, p. ix-xiv, abr.jun. 1967.

GLOECKNER, Ricardo Jacobsen. Nulidades no processo penal brasileiro? Boletim do IBCCRIM, São Paulo, ano 22, n. 262, p. 15, set. 2014. Disponível em: $<$ http://www.ibccrim.org.br/boletim artigo/5188-Nulidades-no-processo-penal-brasileiro>. Acesso em: 5 jan. 2015.

GOMES, Luiz Flávio. Garantias constitucionais e nulidades processuais. Boletim IBCCRIM, São Paulo, n. 4, p. 2, mai. 1993.

LOPES JR., Aury. Direito processual penal e sua conformidade constitucional. 2. ed. Rio de Janeiro: Lumen Juris, v. 2, 2009.

MAIZA, María Cecilia. Garantías constitucionales y nulidades procesales. Revista de Derecho Penal, Buenos Aires, n. 2, p. 451-514, 2001.

MALAN, Diogo Rudge. Defesa penal efetiva. Ciências Penais: Revista da Associação Brasileira de Professores de Ciências Penais, São Paulo, v. 3, n. 4, p. 253-277, jan./jun. 2006.

MASSA, Carlo. Considerazioni sull'art. 93 c.p.p. Rivista Italiana di Diritto e Procedura Penale, Milano, v. 5, p. 238-250, 1952.

MELlO, Marcos Bernardes de. Teoria do fato jurídico. Plano de Existência. 14. ed. São Paulo: Saraiva, 2007.

MIRANDA, Francisco Cavalcanti Pontes de. Tratado de direito privado. 4. ed. São Paulo: Editora Revista dos Tribunais, 1983. t. 3, 4, 5.

NASSIF, Aramis. Nulidade absoluta: não concessão de tempo razoável para a elaboração da tese defensiva. Boletim IBCCRIM. Jurisprudência, São Paulo, v. 15, n. 176, p. 1.097-1.098, jul. 2007.

RAMALHO JUNIOR, Almir Duclerc. Nulidade no Processo Penal: do Tradicional "inferno" teórico a uma racionalidade garantista. In: MOREIRA, Rômulo (Org.). Leituras complementares de processo penal. Salvador: Editora Podivm, 2008. p. 77-96.

SCHIFFRIN, Leopoldo. Función de las nulidades de oficio en el sistema de las nulidades penales. Revista de Derecho Penal, Buenos Aires, n. 2, p. 435-447, 2001.

TAORMINA, Carlo. Diritto processuale penale. Torino: G. Giappichelli, 1995. v. 2. 